\title{
Novel effect of rapamycin on experimental obliterative bronchiolitis
}

\author{
Dustin M. Walters, MD, and Michael S. Mulligan, MD
}

\author{
From the Division of Cardiothoracic Surgery, the University of Washington Medical Center, Seattle, Wash. \\ Disclosures: Authors have nothing to disclose with regard to commercial support. \\ Received for publication Sept 29, 2015; accepted for publication Sept 29, 2015. \\ Address for reprints: Michael S. Mulligan, MD, Division of Cardiothoracic Surgery, University of Washington \\ Medical Center, 1959 NE Pacific St, Box 356310 Room AA-115, Seattle, WA 98195-6310 (E-mail: \\ msmmd@u.washington.edu). \\ J Thorac Cardiovasc Surg 2016;151:317-8 \\ $0022-5223 / \$ 36.00$ \\ Copyright (C) 2016 Published by Elsevier Inc. on behalf of The American Association for Thoracic Surgery \\ http://dx.doi.org/10.1016/j.jtcvs.2015.09.119
}

Despite advancements in immunosuppressive regimens, chronic allograft rejection remains a significant challenge in lung transplantation. The hallmark feature of chronic rejection, bronchiolitis obliterans (BO), clinically manifests as a progressive decline in forced expiratory volume in 1 second and is associated with decreased graft and patient survival. The mammalian target of rapamycin (mTOR) inhibitor, rapamycin, has been described as a potential therapy for $\mathrm{BO},{ }^{1}$ although its mechanism of action is incompletely understood. One likely mechanism is a decrease in proinflammatory cell (ie, fibrocyte, effector B-cell, and T-cell) infiltration. ${ }^{2}$

In this issue of the Journal, Zhao and colleagues ${ }^{3}$ nicely describe a novel mechanism of action for rapamycin in the prevention of $\mathrm{BO}$-infiltration of regulatory B-cells (in addition to regulatory T-cells). This intriguing finding expands upon a paradigm suggesting a bipolarity of immune cells whereby similar cell types can exhibit either pro- or anti-inflammatory phenotypes. Regulatory B-cells, the authors report, secrete anti-inflammatory cytokines such as interleukim-10 and transforming growth factor $\beta 1$, which may be responsible for the recruitment of regulatory T-cells and the attenuation of BO.

Exactly how rapamycin achieves this end result is not completely known. A well-described mechanism of rapamycin is that it binds FK-506, which then blocks mTOR, leading to gap 1-synthesis phase cell cycle arrest and decreased B- and T-cell proliferation. Thus, the decrease in infiltrative fibroblasts and effector B- and T-cells makes rational sense. However, the mechanism for the increased infiltration of regulatory anti-inflammatory B- and T-cells with mTOR inhibition is poorly understood, although other authors have described it as well. ${ }^{4,5}$

Zhao and colleagues ${ }^{3}$ correctly point out the limitations of the murine tracheal transplantation model used in this study, because BO is a disease process of the small airways and not large central airways. However, this model does display some important features of BO and currently represents 1 of the most reliable and reproducible models available. ${ }^{6}$ Regardless of this limitation, the findings are

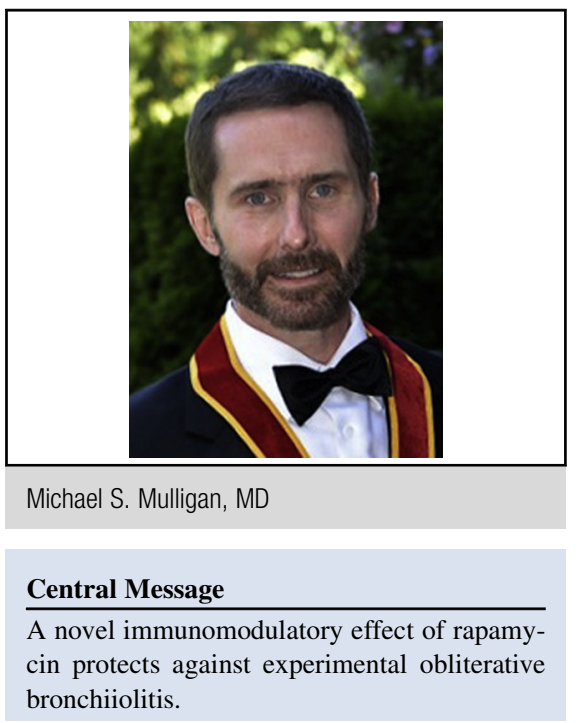

See Article page 487 .

See Editorial Commentary page 497.

important and intriguing and add merit to the evolving understanding of BO. Importantly, this article also sets the stage for future studies to elucidate a more detailed mechanistic understanding of how mTOR inhibition leads to regulatory $\mathrm{B}$ - and $\mathrm{T}$-cell infiltration and the precise role of regulatory $\mathrm{B}$ - and T-cells in attenuation of $\mathrm{BO}$.

A final point worth considering is the safety profile of rapamycin in patients undergoing lung transplant. There is a reported, ${ }^{7}$ and even late, ${ }^{8}$ incidence of anastomotic dehiscence with rapamycin use, and currently many transplant surgeons consider the drug to be contraindicated in the weeks to months following transplantation. Thus, the optimal timing of administration needs consideration. Additionally, rapamycin is poorly tolerated by some patients due to side effects, including pulmonary toxicity, thrombocytopenia, anemia, and wound complications. ${ }^{9}$

Zhao and colleagues ${ }^{3}$ have thoughtfully demonstrated a novel mechanism of rapamycin in the prevention of $\mathrm{BO}$. However, perhaps the most important message-more so than the specific use of rapamycin-is the exploitative potential of regulatory B- and T-cells in BO. Understanding the mechanisms of regulatory cellular infiltration may ultimately drive improved prognostics and therapeutic options for lung transplant recipients. 


\section{References}

1. Sacher VY, Fertel D, Srivastava K, Panos A, Nguyen D, Baxter T, et al. Effects of prophylactic use of sirolimus on bronchiolitis obliterans syndrome development in lung transplant patients. Ann Thorac Surg. 2014;97: 268-74.

2. Gillen JR, Zhao Y, Harris DA, LaPar DJ, Stone ML, Fernandez LG, et al. Rapamycin blocks fibrocyte migration and attenuates bronchiolitis obliterans in a murine model. Ann Thorac Surg. 2013;95:1768-75.

3. Zhao Y, Gillen JR, Meher AK, Burns JA, Kron IL, Lau CL. Rapamycin prevents bronchiolitis obliterans through increasing infiltration of regulatory $\mathrm{B}$ cells in a murine tracheal transplantation model. J Thorac Cardiovasc Surg. 2016;151:487-96.

4. Sauer S, Bruno L, Hertweck A, Finlay D, Leleu M, Spivakov M, et al. T cell receptor signaling controls Foxp3 expression via PI3K, Akt, and mTOR. Proc Natl Acad Sci. 2008;105:7797-802.
5. Delgoffe GM, Kole TP, Zheng Y, Zarek PE, Matthews KL, Xiao B, et al. The mTOR kinase differentially regulates effector and regulatory $\mathrm{T}$ cell lineage commitment. Immunity. 2009;30:832-44.

6. Gomez-de-Antonio D, Campo-Canaveral de la Cruz JL, Gonzalez-Lois C, Santos M, Millan I, Varela de Ugarte A. Heterotopic tracheal transplantation animal model of bronchiolitis obliterans: a reproducible model. Ann Transplant. 2013;18:661-70.

7. King-Biggs MB, Dunitz JM, Park SJ, Kay SS, Hertz MI. Airway anastomotic dehiscence associated with use of sirolimus immediately after lung transplantation. Transplantation. 2003;75:1437-43.

8. Chua AP, Budev M, Mehta A. Late airway anastomotic dehiscence associated with sirolimus and migratory staples in a lung transplant recipient. Chest. 2009;136:1S (4_MeetingAbstracts).

9. Stuckey LJ, Bartos CE, McCullough HA, Florn RD, Lama VN, Lin J, et al. Use of sirolimus in lung transplantation: a single center experience. J Heart Lung Transplant. 2013;32(4 Suppl):S89. 